\title{
The Effect of Adjustment Announcement of Predicted Profit on Price and Trading Volume of Listed Companies in Tehran Stock Exchange
}

\author{
Majid Pakdel ${ }^{1}$, Abbbas Talebbeydokhti 2* \\ ${ }^{1}$ Department of Management, International Qeshm Branch, Islamic Azad University, Qeshm Branch, Qeshm, IRAN \\ 2 Assistant Professor of Financial Management, Department of Management, International Qeshm Branch, Islamic Azad \\ University, Qeshm Branch, Qeshm, IRAN
}

*Corresponding Author: a_beydokhti@yahoo.com

Citation: Pakdel, M. and Talebbeydokhti, A. (2018). The Effect of Adjustment Announcement of Predicted Profit on Price and Trading Volume of Listed Companies in Tehran Stock Exchange. Dutch Journal of Finance and Management, 2(1), 49. https:// doi.org/10.29333/djfm/5825

Published: May 30, 2018

\begin{abstract}
This study investigated the effect of adjustment announcement of predicted profit on price and stocks trading volume of listed companies in Tehran Stock Exchange, in order to determine whether the declaration of adjusted earnings forecast have effect on the two parameters of price and trading volume of the stock or not. In other words, do the declaration adjusted earnings forecast have information content? Therefore, after review of literature collection and formulating hypotheses, data of studied companies was collected and prepared by researchers and eventually the hypotheses were used by econometric models and descriptive statistics and using the Ewies software. The results showed that there was a significant relationship between the amount of the dividend announcement and the date of the announcement; also, there was a significant relationship between the announcement date and the amount of profit with a turnover. So, the announcement of adjusted predicted profit has effect on the stock price and trading volume of stocks.
\end{abstract}

Keywords: adjusted predicted profit, stock price, trading volume of stocks

\section{INTRODUCTION}

One of the important characteristics of each market is the trading volume in which the transaction takes place. In fact, a market of a product is important in the economy which allocates a larger stock of the economy. But the stock market has a fundamental difference with other products in the market. In the market of other products, most of the buyers of the goods are consumers who purchase the product for their needs. Each product has its own elasticity of demand, and consumers should purchase and consume item (or its successor), despite the increase of the prices. However, in the securities market, no one has the basic requirement in securities, and if the price of a type of securities purchased was less unbalanced, the price would be a major factor in the securities market (Ghaemi and Eskandari, 2011). Hence, the identification and measurement of the relationship between stock prices and other factors affecting the market factors will influence future decisions. Capital market is as an important part of the economy, which has stagnated in the community to collect funds in addition to reducing excess liquidity, caused favorable changes to capital investment entities of active market.

In an active market, the stock price reflects the set of all available information and affect the new information of capital on the stock price and also investors based on the available information and expectations of return on equity decide the future plans (Jahankhani \& Safarian, 2004) and this market led to the growth and prosperity and 
Table 1. Studied variables

\begin{tabular}{ccc}
\hline Variables & Symbol & Variable type \\
\hline Logarithm of volume & MM & Independent \\
\hline Logarithm of market prices & LP & Independent \\
\hline The amount of gain adjustment & MABLAGH & dependent \\
\hline Announced date & DATE & dependent \\
\hline Abnormal stock returns & UNUSUAL & Control \\
\hline Expected return & EXPECTED & Control \\
\hline
\end{tabular}

price stock is the most important factor in this market which investors will face. If the predicted profit of each stock contains useful information and effect the decision of consumers, the adjusted predicted profit announcement would change its stock price and it will be declared to the market by the company before the financial year and may be repeated several times in the course of these adjustments. Profit adjustment is one of the most important issues that are the focus of attention for the market's participants.

\section{Theory and Literature}

\section{The relationship between trading volume and price announcement}

In a research which was conducted in the 1970s in the United States, three basic elements were considered in the stock market.

1. Demanding theory to analyze the trend in the stock market price of the stock is not enough and is unable to predict a mechanism for price.

2. The volume of transactions in the commodity market, especially, the economic has more attraction and then, it is considered more by the economists.

3. Stock trading volume and the price of stocks are the two interconnected factors of market mechanisms. Thus, price of each model, regardless of the volume of transactions (or vice versa) will be considered and would lead to mistakes and incomplete results. Kashanipour and Eskandari, (2013) examined the trading volume of stocks and changes of price on the listed Stock Exchange in Tehran. Thus, 257 companies were studied for a period of 7 years from the date 2003/03/21 to 2010/03/21. Hypothesis test results showed that reducing the price limit in 2005/11/12 had significant effect on turnover on equity of companies and increase of trading volume and stock. The result showed that the stock price had an inverse relationship with the volume. Kurdistani and Sepid-dast (2012) investigated the efficiency of stock market reaction to the news as accounting earnings over a period of 9 years (2002 to 2010). Selected samples of 90 companies listed in the Tehran Stock Exchange, based on these assumptions test results indicated that it was the reaction of investors to less-than-expected profit news, which earned the abnormal returns after the profit announcement. That is due to a lack of experience and lack of investors and financial analysts that the financial performance of professional firms to accurately predict the existence of confidential information and information asymmetry is the virgin. Jalali (2011) discussed the relationship between earnings announcement as predicted adjusted profits of per stock, stock price and the trading volume. This study was performed within 4 years (2004 to 2009) in three parts. The results showed that in the first part of the declaration adjusted profit forecast for the whole of the declaration of adjustment (positive and negative) and the announcement of positive adjustment the volume of traded stocks on the volume of trade were affective, but the adjustment did not have negative affect declaration. Also, they found that the adjustments predicted of profit in all three parts (of the declaration, the positive announcement and the announcement of a negative adjustment) had no effect on stock prices. The results of the second and the third parts showed that the adjustment predicted of profit in all three parts (total adjustment notice positive and negative) had impact on stock prices. Choei et al (2010) in a study, entitled the role of seasonal and short-term predicted profits, compared to predictions which were achieved annually of the predicted profit in short-term and the relationship between the returns of the seasonal current and future profits would be increased and the results of this research which can be noted in this case is that accurate seasonal predicted profit of per stock help the investors for better making prediction of future profits.

\section{METHODOLOGY}

This study was correlation -descriptive. Also, the results can be used as an applied research. The study consisted of all companies listed on the Tehran Stock Exchange which were active during the 6-year period of 2008 to 2013 served in the Tehran Stock Exchange. Systematic exclusion method was used to determine the sample size. According to conditions set above, 146 companies were participate in this research and had important characteristics. 
Dutch Journal of Finance and Management, 2(1), 49

Table 2. Estimated results of the first research model (dependent variable: Price) regression

\begin{tabular}{|c|c|c|c|c|c|c|}
\hline \multirow{2}{*}{ Variable } & \multirow{2}{*}{ Coefficient } & \multirow{2}{*}{ T- statistic } & \multirow{2}{*}{ P-value } & \multicolumn{3}{|c|}{ The regression model } \\
\hline & & & & F-stat & PROB & $\mathbf{R}^{2}$ \\
\hline Intercept & 1640795 & 81.49 & 0.000 & & & \\
\hline Log volume & 7763.47 & 2.59 & 0.005 & & & \\
\hline Log market prices & 4616.81 & 2.85 & 0.004 & 115.49 & 0.000 & 0.95 \\
\hline Expected return & 1.50 & 4.61 & 0.000 & & & \\
\hline Unrealistic returns & $366.29-$ & $0.42-$ & 0.67 & & & \\
\hline
\end{tabular}

Table 3. The effect of different variables on the amount of interest payments

\begin{tabular}{ccc}
\hline Variable & Effect & Significant level \\
\hline Log volume & Positive & Significant \\
\hline Log market prices & Positive & Significant \\
\hline
\end{tabular}

Table 4. Estimates properties

\begin{tabular}{ccc}
\hline Obtained statistic & Amount & Result \\
\hline The coefficient of determination & 0.95 & Well chosen variables \\
\hline F-statistic model & 115.49 & Good fit \\
\hline
\end{tabular}

Table 5. The results of the research model (dependent variable: date)

\begin{tabular}{|c|c|c|c|c|c|c|}
\hline \multirow{2}{*}{ Variable } & \multirow{2}{*}{ Coefficient } & \multirow{2}{*}{ T-statistic } & \multirow{2}{*}{ P-value } & \multicolumn{3}{|c|}{ The regression model } \\
\hline & & & & F-stat & PROB & $\mathrm{R}^{2}$ \\
\hline Intercept & 11.54 & 65.05 & 0.000 & & & \\
\hline Log volume & 0.13 & 5.89 & 0.000 & & & \\
\hline Log market prices & 0.01 & 1.20 & 0.21 & 399.99 & 0.000 & 0.98 \\
\hline Expected return & 2.67 & 1.23 & 0.22 & & & \\
\hline Unrealistic returns & $0.006-$ & $1.23-$ & 0.22 & & & \\
\hline
\end{tabular}

Table 6. The effect of different variables on the amount of interest payments

\begin{tabular}{ccc}
\hline Variable & Effect & Significant \\
\hline Log volume & Positive & Meaningful \\
\hline Log of market prices & Positive & Meaningless \\
\hline
\end{tabular}

Table 7. Important properties of estimates

\begin{tabular}{ccc}
\hline Obtained statistic & Amount & Result \\
\hline The coefficient of determination & 0.98 & Well chosen variables \\
\hline F-statistic model & 399.99 & Good fit
\end{tabular}

Table 8. Summarizes the results hypotheses

\begin{tabular}{lll}
\hline Row & Hypotheses & Result \\
\hline Original & There is a significant relationship among the adjusted earnings forecast and stock price and trading volume. & Approve \\
\hline Sub 1 & There is a significant relationship between the stock prices and the amount of interest. & Approve \\
\hline Sub 2 & There is a significant relationship between the stock prices and the date announcement. & Reject \\
\hline Sub 3 & There is a significant relationship between the amount of profit and the turnover. & Approve \\
\hline Sub 4 & There is a significant relationship between the announcement date and the trading volume. & Approve \\
\hline
\end{tabular}

\section{RESULTS}

Tables 2 and 3 shows the estimated results of the first research model (dependent variable: Price) regression and the effect of different variables on the amount of interest payments.

In Table 4, the other results of the first estimation model can be seen.

Considering the fact that there is no specific form of regression residual, it can be concluded that the regression model is well fitted and has no statistical problems.

According to the results, one can notice the effect of different variables on the timing of interest payments as summarized in Table 6.

Other results of the second model estimate can be seen in Table 7.

\section{Summary of the results of research hypotheses}

In this part, the analysis and data analysis related to the hypothesis are presented. In this study, data of the studied company was gathered between years 2008 to 2013 using SPSS software, and Eviews 7 for each year and each participant was tested at 95\% confidence level. The results are shown in the hypotheses in Table 8. 


\section{CONCLUSION}

According to the results of the assumptions of this thesis, the following recommendations are presented:

1. Regarding to this study, it was concluded that the time and the amount of dividends declared predicted variables affect the price and volume of transactions, planning for stability and increased profitability in the Tehran Stock Exchange which has particular importance. It is suggested to the managers and planners to stabilize the exchange offer profit in the future periods, the fluctuations predicted prevent it and by this act go on the price and trading volume fluctuations without advance oscillation over time.

2. Aside from the amount of benefit that the company reach during the period, the relative stability and continuity is very important. Checking the profitability of a company in the course of the past can predict the future relative to us. It is suggested to the investors to invest in companies that profit from greater stability. Regarding to the results of this research, the company will not face with the oscillation in anticipation of profit stability, in terms of price and trading volume.

\section{REFERENCES}

Choei, J. H., Myers, L. A., Zang, Y., Ziebart, D. A. (2010). Do Management Eps forecasts Allow Returns to Reflect future Earnings? Implications for the continuation of management's Quarterly Earning Guidance", Rev Account Stud. https:// doi.org/10.1007/s11142-010-9131-6

Ghaemi, M., Bayat, H. and Eskandari (2011). Management review since the announcement of corporate profits. Journal of Accounting, 3(11), 85-104.

Jahankhani, A. and Safarian, A. (2003). Stock market reaction to the announcement of earnings of per stock estimates in the Stock Exchange of Financial Research.

Kashanipour, M., Salehnejad, R. A. and Yusefimanesh, D. (2013). The effect of varying the price limit on stock returns and trading volume of listed companies in Tehran Stock Exchange. Journal of Accounting, 4(12), 155-174.

Kurdistani, G. R. and Sepid-dast, S. (2012). Performance of the stock market's reaction to news of accounting earnings, accounting tenth national conference on Iran, Alzabra University. 